\title{
Using newborn screening bloodspots for research: public preferences for policy options
}

\author{
Hayeems RZ, Miller FA, Barg CJ, Bombard Y, Cressman C, \\ Painter-Main M, Wilson B, Little J, Allanson J, Avard D, \\ Giguere Y.
}

\author{
Version Post-print/accepted manuscript \\ Citation Hayeems RZ, Miller FA, Barg CJ, Bombard Y, Cressman C, Painter- \\ (published version) Main M, Wilson B, Little J, Allanson J, Avard D, Giguere Y. Using \\ newborn screening bloodspots for research: public preferences for \\ policy options. Pediatrics. 2016 May 17:e20154143.
}

Additional publisher The final version of this article is available from The American information Academy of Pediatrics at https://doi.org/10.1542/peds.2015-4143.

Copyright/License Copyright (C) 2016 by the American Academy of Pediatrics

How to cite TSpace items

Always cite the published version, so the author(s) will receive recognition through services that track citation counts, e.g. Scopus. If you need to cite the page number of the author manuscript from TSpace because you cannot access the published version, then cite the TSpace version in addition to the published version using the permanent URI (handle) found on the record page.

This article was made openly accessible by $U$ of $T$ Faculty. Please tell us how this access benefits you. Your story matters. 


\title{
Using newborn screening bloodspots for research: Public preferences for policy options
}

\author{
Robin Z. Hayeems ${ }^{1,2}$, Fiona A. Miller ${ }^{2}$, Carolyn J Barg², Yvonne Bombard ${ }^{2,3}$, Celine \\ Cressman $^{2}$, Michael Painter-Main², Brenda Wilson ${ }^{4}$, Julian Little ${ }^{4}$, Judith Allanson ${ }^{5}$, \\ Denise Avard ${ }^{6}$, Yves Giguere ${ }^{7}$, Pranesh Chakraborty ${ }^{5}$, June C. Carroll ${ }^{8}$
}

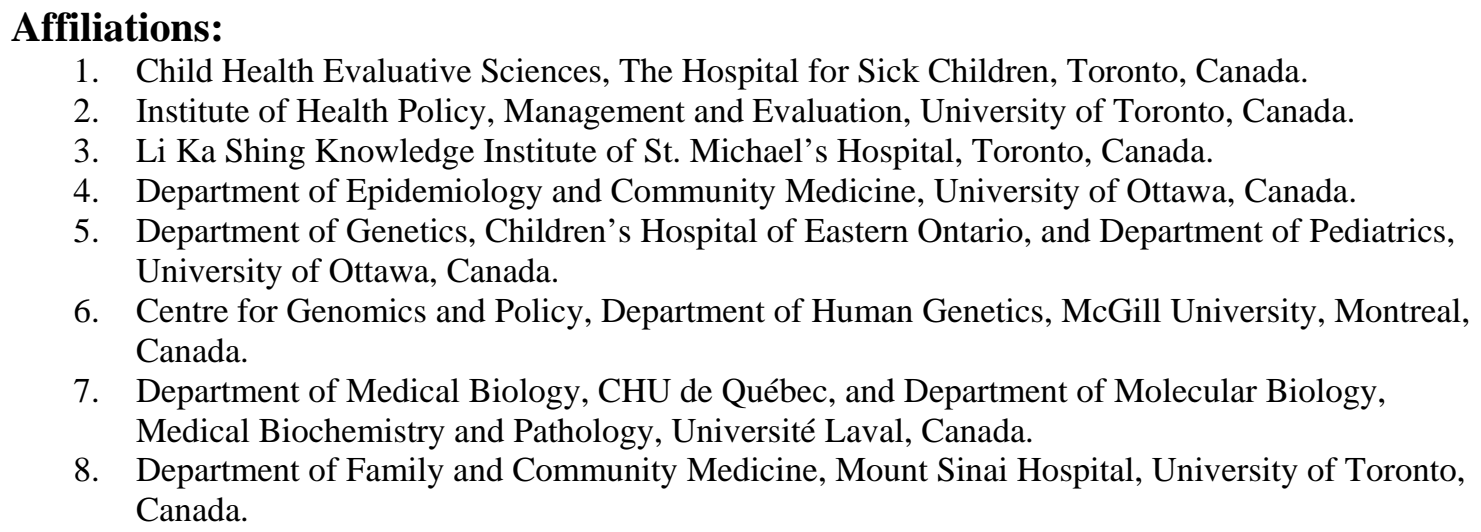

1. Child Health Evaluative Sciences, The Hospital for Sick Children, Toronto, Canada.

2. Institute of Health Policy, Management and Evaluation, University of Toronto, Canada.

3. Li Ka Shing Knowledge Institute of St. Michael's Hospital, Toronto, Canada.

4. Department of Epidemiology and Community Medicine, University of Ottawa, Canada.

5. Department of Genetics, Children's Hospital of Eastern Ontario, and Department of Pediatrics, University of Ottawa, Canada.

6. Centre for Genomics and Policy, Department of Human Genetics, McGill University, Montreal, Canada.

7. Department of Medical Biology, CHU de Québec, and Department of Molecular Biology, Medical Biochemistry and Pathology, Université Laval, Canada.

8. Department of Family and Community Medicine, Mount Sinai Hospital, University of Toronto, Canada.

Address correspondence to: Fiona A. Miller, PhD 155 College Street $4^{\text {th }}$ Floor Toronto, ON M5T 3M6

Short title: Public preferences for research with dried bloodspots

Funding Source: Canadian Institutes of Health Research

Financial Disclosure: The authors have no financial relationships relevant to this article to disclose.

Conflict of Interest: The authors have no conflicts of interest to disclose.

Clinical Trial Registration: N/A

Abbreviations: NBS - newborn screening,

Key Words: newborn screening, secondary use of stored blood samples, public engagement, reasoning

\section{What's Known on This Subject}

Newborn screening programs have traditionally used parental opt-out models to authorize their use of residual newborn screening bloodspots for medical research, but public controversy and recent changes to research policy may challenge current practice.

\section{What This Study Adds}

The public prefers that permission be sought to use NBS samples for research. This preference was diminished but still retained where challenges associated with this option, as well as other policy options, were presented. 
54 FA Miller conceived of and led the study. FA Miller designed the data collection 55 instruments, coordinated and supervised data collection and analysis, critically reviewed 56 the manuscript, and approved the final manuscript as submitted.

57

58 RZ Hayeems assisted with study design and the design of the data collection 59 instruments, participated in the oversight of data collection and analysis, drafted and

60 critically reviewed the manuscript, and approved the final manuscript as submitted.

61

62 CJ Barg, Y Bombard C Cressman assisted with study design and the design of the data 63 collection instruments, participated in the oversight of data collection and analysis, 64 critically reviewed the manuscript, and approved the final manuscript as submitted.

65

66 M Painter-Main conducted the statistical analysis, critically reviewed the manuscript, 67 and approved the final manuscript as submitted.

68

69 B Wilson, J Little, J Allanson, D Avard, Y Giguere, P Chakraborty, JC. Carroll assisted 70 with study design and the design of the data collection instruments, critically reviewed 71 the manuscript, and approved the final manuscript as submitted. 


\section{Abstract}

76 Objective: The retention of residual newborn screening (NBS) bloodspots for medical

77 research remains contentious. To inform this debate, we sought to understand public

78 preferences for, and reasons for preferring, alternative policy options.

79 Methods: We assessed preferences among four policy options for research use of

80 residual bloodspots through a bilingual national internet survey of a representative

81 sample of Canadians. Additionally, $50 \%$ of respondents were randomly assigned to

82 select reasons supporting these preferences. Understanding of screening and research

83 concepts, attitudes towards medical research, and demographics were also assessed.

84 Results: Of 1102 respondents (94\% participation rate; 47\% completion rate), the overall

85 preference among policy options presented was ask permission (67\%); this was also the

86 most acceptable option (80\%). Assume permission was acceptable to 46\%, no

87 permission required was acceptable to $29 \%$, and no research allowed was acceptable to

$8826 \%$. The acceptability of the ask permission option was reduced among participants

89 randomly assigned to the reasoning exercise ( $84 \%$ vs $76 \%$; $p=0.004)$. Compared to

90 assume/no permission required, ordered logistic regression showed significant reduction

91 in preference for the ask permission option with greater understanding of concepts

$92(\mathrm{OR}=0.87, \mathrm{p}<0.001)$, greater confidence in science $(\mathrm{OR}=0.16, \mathrm{p}<0.001)$, and a perceived

93 responsibility to contribute to research $(\mathrm{OR}=0.39, \mathrm{p}<0.001)$.

94 Conclusion: Members of the Canadian public prefer that explicit permission be sought

95 for storage and research use of NBS bloodspots. This preference was diminished but

96 retained when reasons supporting and opposing routine storage, and other policy options

97 were presented. Findings warrant consideration as NBS communities devise new

98 strategies to respond to shifting legislative contexts. 


\section{Introduction}

105 Repositories of residual newborn screening (NBS) bloodspots exemplify the promise

106 and challenge of big data for translational research. They provide unbiased coverage of

107 populations for medical and public health research but raise questions regarding

108 appropriate governance. Policy and practice related to the storage and retention of

109 residual NBS bloodspots for medical research remain variable and contentious. ${ }^{1-5}$

110 Lawsuits have challenged NBS programs’ right to retain samples for research without

111 explicit parental consent, resulting in the destruction of some population-level bio-

112 specimen collections. ${ }^{6-11}$ Yet supporters of the 'opt-out' (i.e. non-explicit consent) model

113 argue that it ensures high participation rates and is simply more feasible than seeking

114 explicit permission from the entire population of pre/post partum parents. ${ }^{12-14}$

116 When engaged in deliberation about the tensions between individual and collective

117 interests, American and Canadian publics are generally supportive of research use of

118 stored samples. ${ }^{1,15,16}$ Where concrete policy options have been proposed, however,

119 majorities favor active permission-based approaches over passive notification/opt-out

120 processes. ${ }^{1,17-21}$ Even genetics professionals perceive risk to secondary uses of

121 bloodspots without permission, including reduced uptake and loss of public trust. ${ }^{22}$

122 Seeking to sustain research capacity while recognizing these concerns, recent guidance

123 emphasizes the importance of transparency regarding the storage and research uses of

124 dried bloodspots but remains ambivalent on the question of consent. Botkin et $\mathrm{al}^{23}$ state,

125 “Either an opt-in or an opt-out approach for enabling parental choice can be ethically 
126 acceptable. In either case, parental education and public transparency are central to the

127 ethical conduct of the program..."

128

129 Despite this apparent flexibility, proposed changes to the Common Rule, prompted by

130 the NBS Saves Lives Reauthorization Act of 2014, suggests that US-federally funded

131 NBS research will require explicit consent for use of bloodspots, eliminating the ability

132 of ethics boards to waive consent. ${ }^{24-27}$ Recent guidance from the American Society of

133 Human Genetics also advocates parental choice regarding the use of bloodspots. ${ }^{28}$ What

134 constitutes informed consent in this context, and how this legislation and professional

135 guidance will affect other jurisdictions, remains unknown. Whether public preferences

136 for explicit consent are robust in the face of practical and value-based challenges

137 associated with consent also remains unknown. To deepen our understanding of public

138 preferences for this complex policy issue and to inform the development of strategies

139 related to storage and use of NBS bloodspots in a shifting legislative context, we report

140 results from a study that engaged the Canadian public on this policy question.

141

142 Methods

143 Sample and data collection

144 We conducted a cross-sectional, bilingual (English, French) national internet survey of a

145 representative sample of Canadians in $2013 .{ }^{29}$ We contracted with Survey Sampling

146 International (SSI), specialists in online data collection for academic and market

147 research. We recruited respondents who met pre-specified criteria for age, sex, and

148 region of residence, in accordance with Statistics Canada data. ${ }^{42}$ We over-sampled 
149 individuals with children $<5$ to allow sub-group analysis comparing parents of young

150 children with others. Eligible participants were sent an email invitation to participate in

151 the survey by following a link. The survey was comprised of three separate sections to

152 optimize survey completion; respondents were given the option to continue after each

153 section, with incentives (rewards points, prize draws, or cash) dependent on the

154 section(s) completed. University of Toronto's Health Sciences Research Ethics Board

155 approved the study.

\section{The questionnaire}

158 The questionnaire was developed by our multidisciplinary team based on previous

159 work ${ }^{15}$ and a literature review. ${ }^{31-36}$ It was pretested through three rounds of face-to-face

160 cognitive interviews $(n=16)$ and piloted with members of the internet panel $(n=87)$ to

161 assess comprehension, face and content validity. The questionnaire was designed to

162 educate respondents and measure knowledge and attitudes related to NBS (Sections

163 1\&2), and the use of residual bloodspots for medical research (Section 3). We provided

164 respondents with essential information about this type of research by specifying three

165 minimum conditions: (i) all research would meet strict scientific and ethical standards

166 (i.e. reviewed and approved by an ethics board); (ii) all personal information would be

167 removed to protect privacy (i.e. ID number used for sample identity, linking to personal

168 health records possible but rigorously secured); and (iii) the NBS program would be

169 responsible for deciding what type of research could be done. The survey included

170 professionally-designed images to convey these concepts in a visually appealing way

171 and included interactive quizzes (Appendix 1) to explain relevant content. 


\section{Measures}

173 We solicited preferences for four specific policy options: no research (the samples are

174 destroyed after NBS, so that no research is possible), ask for permission for research

175 (parents are asked for their permission to store their baby's sample for future research;

176 unless parents agree to research, their baby's sample will not be used), assume

177 permission for research (parents are not asked for their permission to use their baby's

178 sample for future research; permission is assumed but there is a clear process for parents

179 to opt out), and no permission needed for research (parents are not asked for their

180 permission to use their baby's sample for future research; permission is not considered

181 necessary). We specified that if parents are asked for permission, it would be for all

182 potential medical research rather than for one specific study. We asked respondents to

183 rate the acceptability of each policy option on its own (4-point Likert scale: completely

184 or somewhat unacceptable, somewhat or completely acceptable; Appendix 2a) and we

185 included a forced choice question, asking respondents to identify which of the four

186 policy options they preferred overall (Appendix 2b).

188 Understanding of bloodspot storage was assessed using true/false quizzes (ㅅppendix 1).

189 After each concept was explained, a quiz assessed understanding, followed by real-time

190 feedback and corrected answers, as appropriate. We also assessed respondents' trust in

191 medical research using two items from the Eurobarometer Social Values on Science and

192 Technology Survey ${ }^{36}$ (5-point Likert scales from strongly agree, SA to strongly

193 disagree, SD) and one de novo item related to research privacy (Table 4). Views about

194 the importance of the public's involvement in governing medical research, the sense of 
195 personal duty to participate in medical research, and views on the responsibility of

196 others to participate (5-point Likert scales, SA to SD) were also solicited. ${ }^{36}$ We assessed

197 prior awareness that NBS samples could be stored for future research (i.e. samples are

198 currently retained in Canada, albeit with variable consent processes, duration, and

199 research use policies). ${ }^{37}$

200

201 Finally, we drew from Johri et $\mathrm{al}^{31}$ to develop a novel approach to the use of value-based

202 reasoning in the elicitation of public preferences. To test the effect of reasoning on

203 policy preferences, half the respondents were randomly assigned to an exercise that

204 presented them with six pro/con reasons, developed by the authors to represent the most

205 salient, countervailing logics driving this debate. Reasons related to the goal of NBS,

206 the challenge of consent, and trust in the research enterprise. ${ }^{38-40}$ Three reasons

207 supported routinized bloodspot storage: research is an important opportunity, consent

208 has costs, and medical research can be trusted; three reasons opposed routinized storage:

209 research is not the primary goal of NBS, consent is necessary, and research protections

210 aren't always enough (Appendix 3a). Participants were then asked to select the most

211 influential reason for each of their judgments about the acceptability of the four policy

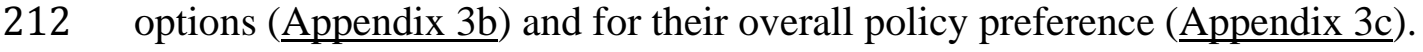

214 Analysis

215 We used descriptive and multivariate statistics, using chi ${ }^{2}$ tests to assess proportional

216 differences where applicable; one-sided p-values of $<0.05$ indicated statistical

217 significance. We produced two composite measures: correct responses to the quizzes 
218 were summed to produce the "understanding of screening and sample storage" measure,

219 scored from 0 to 24 with higher scores indicating greater understanding of these

220 concepts. The "trust in medical research" index was scored from 1-15 and normalized

221 on a 0-1 scale indicating less or more trust in research, respectively. We assessed the

222 reliability of these measures; high Cronbach’s alphas (0.70 each) supported their

223 inclusion in the regression model.

225 To identify the prevailing policy preference and understand the predictors of this

226 preference, including the role of reasoning, we categorized policy preferences as

227 “acceptable," (completely or somewhat acceptable) or "unacceptable,” (completely or

228 somewhat unacceptable). The proportional odds assumption was met (i.e. OR was the

229 same irrespective of the cut-point between "no permission required", "assume

230 permission”, and “ask for permission”), so we used ordinal logistic regression to assess

231 the association between socio-demographic characteristics, knowledge, and attitudes and

232 the most popular policy option. Data were managed and analyzed using Stata (v10.1,

233 StataCorp LP., Station College, Texas).

234

\section{Results}

236 Survey Respondents

237 Response rates are not typically measured for internet surveys, where recruitment is

238 designed to achieve quotas. ${ }^{41}$ The participation rate was $94 \%$, reflecting the proportion

239 of respondents who agreed to participate $(n=2345)$ out of the number of unique

240 individuals who visited the first survey page $(\mathrm{n}=2499)$. The survey completion rate was 
$24147 \%$, reflecting the proportion of respondents who completed all three sections of the

242 survey and met pre-determined response quality criteria from those who agreed to

243 participate (i.e., we removed respondents who completed sections in less than the

244 minimum pre-specified time or 'straight-lined' through the same response column for

245 blocked items). Of the 1102 respondents who completed sections 1-3, 547 were

246 randomized to receive the reasoning exercise.

248 Compared with the general population, the sample was better educated and had higher

249 median income (Table 1; Census $2013^{42}$ ). Compared with those who completed only

250 sections 1 and $2(n=780)$, respondents who completed sections $1-3(n=1102)$ were more

251 likely to be female ( $\mathrm{p}<.001)$, older $(\mathrm{p}<.01)$, and score better on the understanding

252 questions $(\mathrm{p}<.01)$. There were no differences between groups according to the other

253 demographic variables, nor demographic differences between those randomized or not

254 to the reasoning exercise.

256 The prevailing policy preference

257 The rating exercise for each policy option indicated that ask for permission was

258 acceptable (completely or somewhat) to $80 \%$ of respondents, assume permission was

259 acceptable to $46 \%$, no permission needed was acceptable to $29 \%$, and no research was

260 acceptable to $26 \%$. When forced to choose among policy options, ask for permission

261 was selected by the largest proportion (67\%) and no research was selected by the fewest

262 (1\%; Table 2). 


\section{Reasons associated with policy preferences for those randomized}

265 Table 3 summarizes the relationships between the ratings for each of the four policy

266 options (i.e. individually and forced choice), and the reasons available to participants to

267 justify their choices. Across all policy options, the most frequently selected reason

268 endorsed routinized storage (i.e. important research opportunity; up to 85\%), whereas

269 the next most frequently selected reason opposed routinized storage (i.e. consent is

270 necessary; up to 73\%); small minorities selected consent has costs (2-10\%), medical

271 research can be trusted (7-9\%), research is not the goal of NBS (2-4\%), research

272 protections aren't always enough (4-11\%).

273

274 Effect of reasoning exercise

275 Those randomized to the reasoning exercised found the ask permission policy option

276 less acceptable than those not randomized: $76 \%$ vs. $84 \%(\mathrm{p}=0.004)$. Exposure to

277 reasoning was not significantly associated with attitudes toward the acceptability of the

278 other three policy options.

279

280 Attitudes, understanding, and awareness regarding medical research

281 The majority demonstrated a strong understanding of screening and storage concepts

282 once introduced to them (mean=22 $/ 24$ correct, $S D=2.39$ ), though most were unaware

283 that NBS blood samples could be stored for medical research (83\%). Most expressed

284 trust in medical research (81-87\%) and a majority positively valued public involvement

285 in the governance of medical research (65\%). With respect to perceived duties and the

286 responsibilities of others, a majority were disposed to donate their own residual 
287 biological material to medical research (88\%) but fewer believed that others were 288 obliged to do so (33\%; Table 4).

290 Ordinal regression

291 Respondents with lower knowledge and trust scores were more likely to have selected

292 the ask permission policy option ( $\mathrm{OR}=0.88,95 \%$ CI $0.82-0.95$; $\mathrm{OR}=0.14,95 \% \mathrm{CI} 0.04$ -

2930.45 , respectively). This option was also more likely to be selected by those who did not

294 believe it a personal duty or a responsibility of others to participate in research

295 (OR=0.34, 95\% CI 0.14-0.83; OR=0.40, 95\% CI 0.28-0.57; respectively), as well as by

296 those who positively valued public involvement in research governance (OR=1.59, 95\%

297 CI 1.36-1.86; $\mathrm{p}<0.001$ ). Demographic factors (including having children), awareness of 298 sample storage, and participating in the reasoning exercise were not associated with this 299 policy preference (Table 5).

300

301 Discussion

302 In light of ongoing debate related to storage and research uses of newborn bloodspots, 303 our findings provide timely insight. Seeking explicit permission is highly valued, even

304 when respondents are probed, and some of the practical and value-based challenges 305 associated with this approach are exposed. When asked to rate the acceptability of the 306 ask permission policy option on its own, the vast majority of respondents (80\%) were

307 very supportive. Support for this option remain high (76\%) but was significantly

308 reduced among those offered credible reasons for supporting or opposing routinized

309 storage, relative to those not offered such reasons. As well, when forced to choose 
310 among four different policy options, a smaller majority (67\%) selected ask permission

311 than the $80 \%$ who deemed it an acceptable option. Further, the ordered logistic

312 regression suggests that the preference for the ask permission policy option was

313 sensitive to respondents' knowledge about and attitudes towards research more

314 generally. Specifically, a greater understanding of screening and research concepts, trust

315 in research, and a perceived responsibility to participate in research were associated with

316 reduced support for explicit permission.

318 These findings endorse that the public prefers explicit consent, extend related research

319 by identifying the robustness of this preference in the face of reasoning, and highlight

320 public attitudes to which this preference may be sensitive. Arguably, these findings

321 leave the NBS community with two policy options. One option would be to align with

322 the apparent majority preference and develop an explicit permission-based model.

323 While the precise method of consent mandated by NBS Saves Lives Reauthorization Act

324 has not been articulated, an explicit consent approach would presumably meet its bar.

325 However, claims related to lack of feasibility and concerns about reduced uptake

326 persist, ${ }^{12,14}$ and suggest that optimizing voluntariness and collective public health

327 remains a delicate balancing act. There is evidence to suggest that it is feasible to

328 implement permission-based models. ${ }^{17,20,43-45}$ Of note, Charles et $\mathrm{al}^{20}$ tested this

329 approach using a two-stage written consent protocol. They allowed parents to provide

330 separate consent for (i) their baby to be screened and (ii) secondary use of the sample for

331 research. NBS participation remained above $99 \%$ and only $6.5 \%$ of parents opted out of

332 research use. However, other consent-based bio-repository models (e.g. Michigan 
333 BioTrust) achieve more moderate uptake (i.e. 60\%), raising questions about whether

334 explicit consent compromises the ability of programs to conduct generalizable

335 research. ${ }^{43}$

337 A second option might be informed by the results of the logistic regression and the

338 evidence of somewhat diminished enthusiasm for explicit consent among those exposed

339 to the reasoning exercise. Such an approach would mobilize efforts to optimize

340 educational strategies and build trust in order to support a more passive opt-out model.

341 In response to parents' stated preferences for receiving information prenatally about

342 NBS and the use bloodspots for research, ${ }^{1,46-47}$ and the Division of Health and Human

343 Services Secretary's Advisory Committee on Heritable Disorders in Newborns and

344 Children's recommendations regarding these goals, ${ }^{48}$ efforts to develop educational tools

345 are underway. For example, a recent study ${ }^{14}$ identified seven things parents want to

346 know about residual bloodspots (i.e. details about storage, potential uses, risks and

347 burdens, safeguards, anonymity, return of results, and parental choice), and suggested

348 that implementing this knowledge base would improve understanding, trust, and

349 acceptance towards retaining and using stored bloodspots. Whether an opt-out model

350 supported by a robust educational process would comply with the notion of choice

351 recommended by the American Society of Human Genetics, ${ }^{28}$ meet the requirements of

352 NBS Saves Lives Reauthorization Act, ${ }^{27}$ and be feasible to implement remains to be

353 seen.

354 
355 We acknowledge several limitations. First, in presenting the policy options, we did not

356 include parental 'notification' as a specific policy option or as an element of any of the

357 policy options as we could not guarantee that such would occur. Ask permission was,

358 arguably, the only mechanism where parents were involved in an explicit decision.

359 Second, we cannot determine from our findings if respondents’ conceptualized

360 permission as equivalent to the notion of consent, itself having a legal connotation.

361 While an explicit link between permission and consent is made for those randomized to

362 the reasoning exercise, this applies to only half of our respondent group. Third, because

363 of the structure of the questionnaire, which considered screening before issues of storage

364 and research, we cannot shed light on the impact storage policy preferences might have

365 on screening uptake. Fourth, the reasoning exercise had a significant impact on the

366 public's preferences in only one instance; this may be explained by the stability of

367 participant opinion, incomplete ascertainment of considered judgments, the

368 inconsistency of some reasoning, or participant disinterest. A final limitation concerns

369 the structure of our public engagement exercise, which was consultative, rather than

370 deliberative. Recent research suggests the value of deliberative engagements in the

371 context of population screening ${ }^{49-52}$ but our study suggests that carefully composed

372 internet surveys can also be used to elicit considered judgments, and thereby provide

373 more quantitative data on the strength of preferences and the structure of trade-offs. Our

374 efforts to increase the intensity with which participants considered the issue - using an

375 explicit reasoning exercise - were novel, and our findings make an important

376 contribution to the NBS dialogue and to public engagement methodology. 
378 Despite these limitations, we engaged a demographically diverse and representative

379 public in a complex public policy issue using a detailed online training module and a

380 range of strategies to deepen participant involvement. Finally, we reiterate the value of

381 engaging lay publics rather than invested consumers, parents, and professionals since the

382 research at stake is considered to be a public good.

383

384 Conclusions

385 Members of the Canadian public prefer that explicit permission be sought for storage

386 and research use of NBS bloodspots. While enthusiasm for this option was not without

387 qualification, the majority remained committed to an explicit permission model. In the

388 context of a shifting legislative context, these findings warrant consideration.

389

390 
Table 1: Survey Respondents*

\begin{tabular}{|c|c|c|}
\hline & & $N(\%)$ \\
\hline \multirow[t]{2}{*}{ Gender $(\mathrm{n}=1102)$} & Female & $586(53.2)$ \\
\hline & Male & $516(46.8)$ \\
\hline \multirow[t]{3}{*}{ Age } & $18-35$ & $283(25.7)$ \\
\hline & $36-54$ & $446(40.5)$ \\
\hline & $55+$ & $373(33.8)$ \\
\hline \multirow[t]{2}{*}{ Marital Status } & Married/Common Law & $688(62.4)$ \\
\hline & Single/separated/divorced/widowed & 414 (37.6) \\
\hline \multirow[t]{4}{*}{ Geographic Region } & Eastern Canada & $84(7.6)$ \\
\hline & Quebec & $256(23.2)$ \\
\hline & Ontario & $420(38.1)$ \\
\hline & Western Canada & $342(31.0)$ \\
\hline \multirow[t]{3}{*}{ Community Size } & Less than 30,000 & $282(25.6)$ \\
\hline & $30,000-499,999$ & $445(40.4)$ \\
\hline & $500,000+$ & $375(34.0)$ \\
\hline \multirow[t]{4}{*}{ Income } & Less than $\$ 40,000$ & $358(32.5)$ \\
\hline & $\$ 40,000-\$ 79,999$ & $375(34.0)$ \\
\hline & $\$ 80,000+$ & $287(26.0)$ \\
\hline & Preferred not to say & $82(7.4)$ \\
\hline \multirow{3}{*}{$\begin{array}{l}\text { Highest Education } \\
\text { Completed (n=1090) }\end{array}$} & High school or less & 347 (31.8) \\
\hline & College/other post-secondary & $400(36.7)$ \\
\hline & University (undergrad/grad) & $343(31.5)$ \\
\hline \multirow[t]{4}{*}{ Children } & Have children & $735(66.8)$ \\
\hline & Planning or pregnant $\mathrm{w} / \mathrm{o}$ children & $111(10.1)$ \\
\hline & No plans to have children & $108(9.8)$ \\
\hline & Other** & $147(13.4)$ \\
\hline \multirow[t]{2}{*}{ Children under 5} & Yes & $188(25.6)$ \\
\hline & No & $547(74,4)$ \\
\hline \multirow{3}{*}{$\begin{array}{l}\text { Family history of genetic } \\
\text { disease }\end{array}$} & Yes & $188(17.0)$ \\
\hline & No & $851(77.2)$ \\
\hline & Other (i.e. prefer not to say) & $63(5.7)$ \\
\hline
\end{tabular}

$393 *$ Respondents who completed Section 3 of the survey

$394 * *$ These individuals were $\geq 50$ years of age and reported not having children; they were, therefore, not 
Table 2: Results of policy options rating exercise $(\mathrm{N}=1102)$

\begin{tabular}{|c|c|c|c|c|c|}
\hline \multirow[t]{2}{*}{ Policy Options } & \multicolumn{4}{|c|}{ Acceptability of each policy option N(\%) } & \multirow{2}{*}{$\begin{array}{l}\text { When forced } \\
\text { to choose } \\
\text { among policy } \\
\text { options }\end{array}$} \\
\hline & $\begin{array}{l}\text { Completely } \\
\text { Unacceptable }\end{array}$ & $\begin{array}{c}\text { Somewhat } \\
\text { Unacceptable }\end{array}$ & $\begin{array}{l}\text { Somewhat } \\
\text { Acceptable }\end{array}$ & $\begin{array}{l}\text { Completely } \\
\text { Acceptable }\end{array}$ & \\
\hline No research & 418 (37.9) & 399 (36.2) & 185 (16.8) & $100(9.1)$ & $15(1.4)$ \\
\hline $\begin{array}{l}\text { Ask permission } \\
\text { for research }^{\mathrm{a}}\end{array}$ & 59 (5.4) & 161 (14.6) & 297 (27.0) & $585(53.1)$ & 742 (67.3) \\
\hline $\begin{array}{l}\text { Assume } \\
\text { permission for } \\
\text { research }^{b}\end{array}$ & $282(25.6)$ & 305 (27.7) & 329 (29.9) & $186(16.9)$ & 207 (18.8) \\
\hline $\begin{array}{l}\text { No permission } \\
\text { needed for } \\
\text { research }\end{array}$ & $524(47.5)$ & $258(23.4)$ & $190(17.2)$ & $130(11.8)$ & 138 (12.5) \\
\hline
\end{tabular}

$400 \quad{ }^{\mathrm{a}}$ Ask permission vs. assume permission $p<.001$

401 b Assume permission vs. no permission needed for research $p<.001$

402

403

404

405

406

407 
Table 3: Policy option ratings by reasons selected ${ }^{1}$

${ }^{1}$ Sub-sample randomized to reasoning exercise only ( $\left.\mathrm{n}=547\right)$

\begin{tabular}{|c|c|c|c|c|c|c|}
\hline \multirow{3}{*}{$\begin{array}{l}\text { Policy Option } \\
\text { Rating }^{2}\end{array}$} & \multicolumn{6}{|c|}{ Reason Selected N(\%) } \\
\hline & \multicolumn{3}{|c|}{$\begin{array}{c}\text { Reasons that favour routinized } \\
\text { storage }\end{array}$} & \multicolumn{3}{|c|}{$\begin{array}{c}\text { Reasons that do not favour } \\
\text { routinized storage }\end{array}$} \\
\hline & $\begin{array}{l}\text { Important } \\
\text { research } \\
\text { opportunity }\end{array}$ & $\begin{array}{l}\text { Consent has } \\
\text { costs }\end{array}$ & $\begin{array}{l}\text { Medical } \\
\text { research } \\
\text { can be } \\
\text { trusted }\end{array}$ & $\begin{array}{l}\text { Research is } \\
\text { not the goal }\end{array}$ & $\begin{array}{l}\text { Consent is } \\
\text { necessary }\end{array}$ & $\begin{array}{c}\text { Research } \\
\text { protections } \\
\text { aren't } \\
\text { always } \\
\text { enough }\end{array}$ \\
\hline \multicolumn{7}{|l|}{ No research allowed } \\
\hline $\begin{array}{l}\text { Acceptable } \\
\mathrm{n}=133(24)\end{array}$ & $30(22.6)$ & $9(6.8)$ & $15(11.3)$ & $15(11.3)$ & $48(36.1)$ & $16(12.0)$ \\
\hline $\begin{array}{l}\text { Not acceptable } \\
n=414(76)\end{array}$ & $333(80.4)$ & $1(0.002)$ & $35(8.4)$ & $9(2.2)$ & $33(8.0)$ & $3(0.007)$ \\
\hline \multicolumn{7}{|c|}{ Ask permission for research } \\
\hline $\begin{array}{l}\text { Acceptable } \\
\mathrm{n}=414(76)\end{array}$ & $93(22.5)$ & $12(2.9)$ & $19(4.6)$ & $6(1.4)$ & $259(62.6)$ & $25(6.0)$ \\
\hline $\begin{array}{l}\text { Not acceptable } \\
\mathrm{n}=133(24)\end{array}$ & $61(45.9)$ & $21(15.8)$ & $21(15.8)$ & $7(5.3)$ & $20(15.0)$ & $3(2.2)$ \\
\hline \multicolumn{7}{|c|}{ Assume permission for research } \\
\hline $\begin{array}{l}\text { Acceptable } \\
\mathrm{n}=254(46)\end{array}$ & $99(39.0)$ & $44(17.3)$ & $39(15.4)$ & $5(2.0)$ & 49 (19.3) & $18(7.1)$ \\
\hline $\begin{array}{l}\text { Unacceptable } \\
\mathrm{n}=293 \text { (54) }\end{array}$ & $32(10.9)$ & $11(3.8)$ & $9(3.1)$ & $11(3.8)$ & $198(67.6)$ & $32(10.9)$ \\
\hline \multicolumn{7}{|c|}{ No permission required for research } \\
\hline $\begin{array}{l}\text { Acceptable } \\
\mathrm{n}=167(30)\end{array}$ & $98(58.7)$ & $16(9.6)$ & $30(18.0)$ & $1(0.006)$ & $15(9.0)$ & $7(4.2)$ \\
\hline $\begin{array}{l}\text { Unacceptable } \\
\mathrm{n}=380(70)\end{array}$ & $19(5.0)$ & $11(2.9)$ & $8(2.1)$ & $14(3.7)$ & 277 (72.9) & $51(13.4)$ \\
\hline \multicolumn{7}{|l|}{ Forced Choice } \\
\hline $\begin{array}{l}\text { No research } \\
\text { allowed } n=4(0.7)\end{array}$ & $0(0.0)$ & $0(0.0)$ & $0(0.0)$ & $2(50.0)$ & $1(25.0)$ & $1(25.0)$ \\
\hline $\begin{array}{l}\text { Ask permission for } \\
\text { research } n=368 \\
(67.3)\end{array}$ & 99 (26.9) & $5(1.4)$ & $13(3.5)$ & $5(1.4)$ & $224(60.9)$ & $22(6.0)$ \\
\hline $\begin{array}{l}\text { Assume permission } \\
\text { for research } n=103 \\
\text { (18.8) }\end{array}$ & $65(63.1)$ & $16(15.5)$ & $11(10.7)$ & $2(1.9)$ & $7(6.8)$ & $2(1.9)$ \\
\hline $\begin{array}{l}\text { No permission } \\
\text { required } n=72 \\
(13.2)\end{array}$ & $61(84.7)$ & $1(1.4)$ & $10(13.9)$ & $0(0.0)$ & $0(0.0)$ & $0(0.0)$ \\
\hline
\end{tabular}

411 2 "Acceptable" = completely acceptable + somewhat acceptable; "Unacceptable" = completely

412 unacceptable + somewhat unacceptable

413 
414 Table 4: Respondents' knowledge, awareness, and attitudes related to newborn 415 screening and medical research

416

\begin{tabular}{|c|c|c|c|}
\hline Construct & \multicolumn{2}{|l|}{ Item } & \multirow{2}{*}{$\begin{array}{c}\text { Total } \\
(\mathbf{n}=1102) \\
\mathbf{n}(\%)\end{array}$} \\
\hline KNOWLEDGE $^{\wedge}$ & $\begin{array}{l}\text { Index of understanding } \\
\text { composite score (max=24), } \\
\text { mean (SD) }\end{array}$ & 21.72 (2.39) & \\
\hline \multirow[t]{2}{*}{ AWARENESS } & \multirow[b]{2}{*}{$\begin{array}{l}\text { Aware that blood samples } \\
\text { collected for NBS could be } \\
\text { stored \& made available for } \\
\text { (before completing } \\
\text { questionnaire) }\end{array}$} & Yes & $191(17.3)$ \\
\hline & & No & $911(82.7)$ \\
\hline \multicolumn{4}{|l|}{ ATTITUDES } \\
\hline \multirow{9}{*}{$\begin{array}{l}\text { Trust in medical } \\
\text { research* }\end{array}$} & \multirow{3}{*}{$\begin{array}{l}\text { Medical research will help } \\
\text { to cure illnesses such as } \\
\text { AIDS, cancer }\end{array}$} & Strongly agree/agree & $956(86.8)$ \\
\hline & & Neutral & $119(10.8)$ \\
\hline & & $\begin{array}{l}\text { Strongly } \\
\text { disagree/disagree }\end{array}$ & $27(2.4)$ \\
\hline & \multirow{3}{*}{$\begin{array}{l}\text { Most medical researchers } \\
\text { want to work on things that } \\
\text { will make life better for the } \\
\text { average person }\end{array}$} & Strongly agree/agree & $918(83.3)$ \\
\hline & & Neutral & $143(13.0)$ \\
\hline & & $\begin{array}{l}\text { Strongly } \\
\text { disagree/disagree }\end{array}$ & $41(3.7)$ \\
\hline & \multirow{3}{*}{$\begin{array}{l}\text { The privacy and } \\
\text { confidentiality of people } \\
\text { who participate in medical } \\
\text { research will be protected }\end{array}$} & Strongly agree/agree & $891(80.9)$ \\
\hline & & Neutral & $176(16.0)$ \\
\hline & & $\begin{array}{l}\text { Strongly } \\
\text { disagree/disagree }\end{array}$ & $35(3.2)$ \\
\hline \multirow{3}{*}{$\begin{array}{l}\text { Public } \\
\text { involvement in } \\
\text { research } \\
\text { governance }\end{array}$} & \multirow{3}{*}{$\begin{array}{l}\text { To direct medical research } \\
\text { in the right way, it would be } \\
\text { better to take more account } \\
\text { of what the public thinks, in } \\
\text { other words people like you } \\
\text { and me }\end{array}$} & Strongly agree/agree & $718(65.2)$ \\
\hline & & Neutral & $281(25.5)$ \\
\hline & & $\begin{array}{l}\text { Strongly } \\
\text { disagree/disagree }\end{array}$ & $103(9.3)$ \\
\hline \multirow{3}{*}{$\begin{array}{l}\text { Willingness to } \\
\text { participate in } \\
\text { research }\end{array}$} & \multirow{3}{*}{$\begin{array}{l}\text { After my doctor uses my } \\
\text { blood sample for my care, I } \\
\text { would let my leftover } \\
\text { sample be used for medical } \\
\text { research }\end{array}$} & Strongly agree/agree & $965(87.6)$ \\
\hline & & Neutral & $84(7.6)$ \\
\hline & & $\begin{array}{l}\text { Strongly } \\
\text { disagree/disagree }\end{array}$ & $53(4.8)$ \\
\hline \multirow{3}{*}{$\begin{array}{l}\text { Perceived } \\
\text { obligation of } \\
\text { others to } \\
\text { participate in } \\
\text { research }\end{array}$} & \multirow{3}{*}{$\begin{array}{l}\text { After a doctor uses a blood } \\
\text { sample for someone's } \\
\text { health care, I think it would } \\
\text { be irresponsible for them to } \\
\text { refuse to let their leftover } \\
\text { sample be used for medical } \\
\text { research }\end{array}$} & Strongly agree/agree & $362(32.8)$ \\
\hline & & Neutral & $367(33.3)$ \\
\hline & & $\begin{array}{l}\text { Strongly } \\
\text { disagree/disagree }\end{array}$ & $373(33.8)$ \\
\hline
\end{tabular}


421 Table 5. Predictors of “Ask for permission” Policy Preference†: Ordered Logistic

422 Regression

\begin{tabular}{|c|c|}
\hline & $\begin{array}{l}\text { “Ask Permission” } \\
\text { Policy Preference } \\
\text { Odds Ratio (SE) }\end{array}$ \\
\hline \multicolumn{2}{|l|}{ Demographics } \\
\hline \multicolumn{2}{|l|}{ Gender (Reference: Male) } \\
\hline Female (CI 0.74-1.38) & $1.01(.16)$ \\
\hline \multicolumn{2}{|l|}{ Age (Reference: $55+$ ) } \\
\hline $18-35(\mathrm{CI} 0.81-2.30)$ & $1.36(.36)$ \\
\hline 36-54 (CI 0.78-1.64) & $1.14(.21)$ \\
\hline \multicolumn{2}{|l|}{ Geographic Region (Reference: Quebec) } \\
\hline Eastern Canada (CI 0.48-1.59) & $.88(.27)$ \\
\hline Ontario (CI 0.72-1.57) & $1.07(.21)$ \\
\hline Western Canada (CI 0.89-2.04) & $1.35(.28)$ \\
\hline \multicolumn{2}{|l|}{ Income (Reference: $\$ 80,000+$ ) } \\
\hline Less than $\$ 40,000$ (CI $0.90-2.12)$ & $1.39(.30)$ \\
\hline$\$ 40,000-\$ 79,999$ (CI 0.78-1.64) & $1.13(.21)$ \\
\hline \multicolumn{2}{|l|}{ Education (Reference: Post-Sec.) } \\
\hline High-School or less (CI 0.66-1.50) & $1.00(.21)$ \\
\hline College/CEGEP (CI 0.76-1.61) & $1.11(.21)$ \\
\hline \multicolumn{2}{|l|}{ City Size (Reference: 500,000+) } \\
\hline Less than 30,000 (CI 0.75-1.72) & $1.13(.24)$ \\
\hline 30,000-499,999 (CI 0.52-1.05) & $.74(.13)+$ \\
\hline \multicolumn{2}{|l|}{ Relationship Status (Reference: Not married/not common law) } \\
\hline Married/Common law (CI 0.84-1.66) & $1.18(.21)$ \\
\hline \multicolumn{2}{|l|}{ Children (Reference: Kids Under 5) } \\
\hline Kids Over 4 (CI 0.49-1.32) & $.80(.20)$ \\
\hline Plan/Pregnant, No Kids (CI 0.66-2.33) & $1.24(.40)$ \\
\hline No Plan/Pregnant, No Kids (CI 0.38-1.18) & $.67(.19)$ \\
\hline \multicolumn{2}{|l|}{ Knowledge/Awareness } \\
\hline Index of understanding ${ }^{\mathrm{a}}$ (CI 0.82-0.95) & $.88(.03)^{* * *}$ \\
\hline $\begin{array}{l}\text { Aware of sample storage for medical research (CI 0.70-1.51) (Reference: not } \\
\text { aware) }\end{array}$ & $1.03(.20)$ \\
\hline \multicolumn{2}{|l|}{ Attitudes Towards Research } \\
\hline Trust in medical research ${ }^{\mathrm{b}}$ (CI 0.04-.45) (Reference: Not agree on trust items) & $.14(.08) * * *$ \\
\hline Public involvement important (CI 1.36-1.86) (Reference: Not important) & $1.59(.12) * * *$ \\
\hline \multicolumn{2}{|l|}{ Personal duty to participate (Reference: Neutral) } \\
\hline Disagree personal duty (CI 0.13-2.07) & $.51(.36)$ \\
\hline Agree personal duty (CI .14-.83) & $.34(.16) *$ \\
\hline \multicolumn{2}{|l|}{ Perceived responsibility of others to participate (Reference: Neutral) } \\
\hline Disagree irresponsible of others not to donate (CI .92-2.01) & $1.37(.27)$ \\
\hline Agree irresponsible of others not to donate (CI 0.28-0.57) & $.40(.07)^{* * *}$ \\
\hline Reasoning exercise (CI 0.67-1.22) & $.91(.14)$ \\
\hline Pseudo R-squared & .12 \\
\hline $\mathrm{N}$ & 914 \\
\hline Test of Proportionality of Odds & $24.24(\mathrm{p}>.05)$ \\
\hline Brant Test of Parallel Regression Assumption & $29.54(\mathrm{p}>.05)$ \\
\hline
\end{tabular}

$423+$ DV is $0=$ "No permission required"; $1=$ "assume permission” $2=$ ="“ask for permission”

$+\mathrm{p}<.10 * \mathrm{p}<.05 * *<\mathrm{p} .01 * * * \mathrm{p}<.001$

${ }^{a}$ Index sums the number of correct responses given to 24 questions (Alpha $=0.70$ )

bSelected items from the Eurobarometer's Social Values on Science and Technology Survey.31 "Trust in Medical Research" index created (Alpha $=.70 ; 0-1$ scale, mean $=.80, \mathrm{SD}=0.16) ; \sim \mathrm{CI}-95 \%$ confidence interval 


\section{REFERENCES}

429

430

431

432

433

434

435

436

437

438

439

440

441

442

443

444

445

446

447

448

449

450

451

452

453

454

455

456

457

458

459

460

461

462

463

464

465

466

467

468

469

470

471

472

473
1. Botkin JR, Rothwell E, Anderson R, Stark L, Goldenberg A, Lewis M, et al. Public attitudes regarding the use of residual newborn screening specimens for research. Pediatr 2012; 129: 231-58.

2. Petrini C, Olivieri A, Corbetta C, Cerone R, D'Agnolo G, Bompiani A.Common criteria among States for storage and use of dried blood spot specimens after newborn screening. Ann Ist Super Sanita. 2012;48(2):119-21. doi: DOI: 10.4415/ANN_12_02_03.

3. Douglas CM, van El CG, Faulkner A, Cornel MC. Governing biological material at the intersection of care and research: the use of dried bloodspots for biobanking. Croat Med J. 2012 Aug;53(4):390-7.

4. Chrysler D, McGee H, Bach J, Goldman E, Jacobson PD. The Michigan Biotrust for Health: Using dried bloodspots for research to benefit the community while respecting the individual. J Law Med Ethics 2011; 39:98-101.

5. Tarini BA. Storage and use of residual newborn screening bloodspots: a public policy emergency. Genet Med. 2011 Jul;13(7):619-20. doi:

10.1097/GIM.0b013e31822176df.

6. Couzin-Frankel J. Newborn blood collections. Science gold mine, ethical minefield. Science 2009; 324:166-8.

7. Citizens Council. Nine Families Sue State of Minnesota—Allege Violations of State Genetic Privacy Law in Newborn Screening. Medical News Today. May 12, 2009. http://www.medicalnewstoday.com/releases/142005.php. Accessed July 16, 2014.

8. Wilson N. Newborn DNA samples to be destroyed suit: secret genetic testing on newborns improper. KXAN. December 22, 2009. www.kxan.com/dpp/ news/texas/settlement-in-newborn-dnalawsuit. Accessed August 12, 2010.

9. Neergaard L. Newborn testing faces challenges in using leftover bloodspots for research. The Associated Press 2010. http://lifestyle.ca.msn.com/healthfitness/news/canadianpress-article. aspx?cp-documentid=23423878. Accessed August 12, 2010.

10. Armstrong J. Storage of newborns' blood samples raises privacy concerns. The Globe and Mail. May 11, 2010: S1.

11. McLean E. Protocols' secrecy queried. Otago Daily Times. April 23, 2011. www.odt.co.nz/news/dunedin/157327/ protocols-secrecy-queried. Accessed May 18, 2011. 
474

475

476

477

478

479

480

481

482

483

484

485

486

487

488

489

490

491

492

493

494

495

496

497

498

499

500

501

502

503

504

505

506

507

508

509

510

511

512

513

514

515

516

517

518

519

520
12. Feuchtbaum L, Cunningham G, Sciortino S. Questioning the need for informed consent: a case study of California's experience with a pilot newborn screening research project. J Empir Res Hum Res Ethics 2007;2:3-14.

13. Taylor HA, Wilfond BS. Ethical issues in newborn screening research: lessons from the Wisconsin cystic fibrosis trial. J Pediatr 2004;145:292-96.

14. Botkin JR, Lewis MH, Watson MS, Swoboda KJ, Anderson R, Berry SA, et al. Parental permission for pilot newborn screening research: Guidelines from the NBSTRN. Pediatr 2014; 133: e410-17.

15. Bombard Y, Miller FA, Hayeems RZ, Carroll JC, Little J, Allanson J, et al. Citizens' values regarding research with stored samples from newborn screening. Pediatr 2012;129:239-47.

16. Duquette D, Langbo C, Bach J, Kleyn M. Public support for using residual dried blood spot samples for health research. Public Health Genomics. 2012;15(34):146-55. doi: 10.1159/000336565. Epub 2012 Apr 4.

17. Tarini BA, Goldenberg A, Singer D, Clark SJ, Butchart A, Davis MM. Not without my permission: parents' willingness to permit use of newborn screening samples for research. Public Health Genomics 2010;13:125-30.

18. Newcomb P, True B, Walsh J, Dyson M, Lockwood S, Douglas B. Maternal attitudes and knowledge about newborn screening. MCN 2013; 38: 289-94.

19. Thiel DB, Platt T, Platt J, King, SB, Kardia SLR. Community perspectives on public health biobanking: an analysis of community meetings on the Michigan Biotrust for Health. J Community Genet 2014; 5:125-38.

20. Charles T, Pitt J, Halliday J, Amor DJ. Implementation of written consent for newborn screening in Victoria, Australia. J Pediatr Child Health 2014; 50:399404.

21. Gong LM, Tu WJ, He J, Shi XD, Wang XY, Li Y. The use of newborn screening dried bloodspots for research: the parental perspective. J Bioeth Inq. 2012 Jun; 9(2):189-93. doi: 10.1007/s11673-012-9368-9. Epub 2012 Mar 21.

22. Richer J, Ghebremichael MS, Chudley AE, Robinson, WM, Wilfond BS, Solomon MZ. Researcher use of leftover newborn bloodspots: Attitudes of Canadian geneticists regarding storage and informed consent requirements. Gen Med 2011; 13:305-13.

23. Botkin JR, Goldenburg AJ, Rothwell E, Anderson RA, Lewis MH. Retention and research use of residual newborn screening bloodsports. Pediatr 2013; 131: 12027. 
24. Human Subjects Research Protections: Enhancing Protections for Research Subjects and Reducing Burden, Delay, and Ambiguity for Investigators. The Office of the Secretary, HHS, and the Food and Drug Administration. Available from: http://www.gpo.gov/fdsys/pkg/FR-2011-07-26/html/2011-18792.htm Accessed on July 14, 2014.

25. US Department of Health and Human Services. ANPRM for Revision to Common Rule. US Department of Health and Human. Available from: http://www.hhs.gov/ohrp/humansubjects/anprm2011page.html Accessed on: July 14, 2014.

26. Javitt GH. Take another little piece of my heart: Regulating the research of human biospecimens. J Law Med Ethics 2013; 41:424-39.

27. Newborn Screening Saves Lives Reauthorization Act of 2014. Public Law No: 113-240. Available at: http://www.gpo.gov/fdsys/pkg/PLAW113publ240/pdf/PLAW-113publ240.pdf Accessed on: August 5, 2015.

28. Botkin JR, Belmont JW, Berg JS, Berkman BE, Bombard Y, Holm IA, Levy HP, Ormond KE, Saal HM, Spinner NB, Wilfond BS, McInerney JD. Points to Consider: Ethical, Legal, and Psychosocial Implications of Genetic Testing in Children and Adolescents. Am J Hum Genet. 2015 Jul 2;97(1):6-21.

29. Miller FA, Hayeems RZ, Bombard Y, Cressman C, Barg CJ, Carroll JC, Wilson BJ, Little J, Allanson J, Chakraborty P, Giguère Y, Regier DA. Public Perceptions of the Benefits and Risks of Newborn Screening. Pediatr. 2015 Aug;136(2):e413-23.

30. Hayeems RZ, Bombard Y, Miller FA, Carroll JC, Little J, Allanson J, et al. Beliefs and values about expanded newborn screening: A public engagement study. Health Expect 2015 Jun;18(3):419-29. doi: 10.1111/hex.12047. Epub 2013 Feb 1.

31. Johri M, Damschroder LJ, Zikmund-Fisher BJ, Kim SY, Ubel PA. Can a moral reasoning exercise improve response quality to surveys of healthcare priorities? J Med Ethics 2009;35:57-64.

32. Willison DJ, Swinton M, Schwartz L, Abelson J, Charles C, Northrup D, et al. Alternatives to project-specific consent for access to personal information for health research: insights from a public dialogue. BMC Med Ethics. 2008;9:18.

33. Schwartz LM, Woloshin S, Fowler FJ, Jr., Welch HG. Enthusiasm for cancer screening in the United States. JAMA 2004;291:71-78. 
34. Straten GF, Friele RD, Groenewegen PP. Public trust in Dutch health care. Soc Sci Med 2002;55:227-234.

35. Kim M, Blendon RJ, Benson JM. How interested are Americans in new medical technologies? A multicountry comparison. Health Aff (Millwood) 2001;20:194201.

36. Gaskell G, Allansdottir A, Allum N, Castro, P, Esmer Y, Fischler, C. The 2010 Eurobarometer on the life sciences. Nat Biotechnol 2011;29:113-14.

37. Avard D, Vallance H, Greenberg C, Laberge C, Kharaboyan L, Plant M (2006) Variability in the storage and use of newborn dried bloodspots in Canada: is it time for national standards? Genomics Soc Policy 2(3):80-95

38. Secko D. M., Preto N., Niemeyer S., Burgess M. M. Informed consent in biobank research: a deliberative approach to the debate. Soc Sci Med. 2009;68(4):781-789.

39. Rothwell E., Anderson R., Botkin J. Policy issues and stakeholder concerns regarding the storage and use of residual newborn dried blood samples for research. Policy Polit Nurs Pract. 2010;11(1):5-12.

40. Simon et al. Active Choice but not too active: Public perspectives on biobank consent models. Genetics in Medicine, Vol 13(9), September 2011.

41. Eysenbach G. Improving the quality of Web surveys: the Checklist for Reporting Results of Internet E-Surveys (CHERRIES). J Med Internet Res 2004;6(3):e34.

42. Statistics Canada. Census of Population. 2006. http://www12.statcan.gc.ca/census487 recensement/2011/rt-td/indexeng.cfm\#tab5. Accessed March 21, 2013.

43. Langbo C, Bach J, Kleyn M, Pouch Downes F. From Newborn Screening to Population Health Research: Implementation of the Michigan BioTrust for Health. Public Health Reports / September-October 2013 / Volume 128

44. Dhondt JL. Implementation of informed consent for a cystic fibrosis newborn screening program in France: low refusal rates for optional testing. J Pediatr 2005;147:S106-8.

45. Liebl B, Nennstiel-Ratzel U, von Kries R et al. Very high compliance in an expanded MS-MS-based newborn screening program despite written parental consent. Prev Med 2002;34:127-31. 
46. Kerruish NJ, Webster D, Dickson N. Information and consent for newborn screening: practices and attitudes of service providers. J Med Ethics

613

614

615

616

617

618

619

620

621

622

623

624

625

626

627

628

629

630

631

632

633

634

635

636

637

638

639

640

641

642

643

644

645

646

647

648

47. Rothwell E, Anderson R, Goldenberg A, Lewis MH, Stark L, Burbank M, Wong $\mathrm{B}$, Botkin JR. Assessing public attitudes on the retention and use of residual newborn screening blood samples: a focus group study. Soc Sci

Med. 2012 Apr;74(8):1305-9. doi: 10.1016/j.socscimed.2011.12.047. Epub 2012 Feb 18.

48. Therrell BL Jr1, Hannon WH, Bailey DB Jr, Goldman EB, Monaco J, NorgaardPedersen B, Terry SF, Johnson A, Howell RR. Committee report: Considerations and recommendations for national guidance regarding the retention and use of residual dried blood spot specimens after newborn screening. Genet Med. 2011 Jul;13(7):621-4. doi: 10.1097/GIM.0b013e3182147639.

49. Rychetnik L, Doust J, Thomas R, et al. A Community Jury on PSA screening: what do well-informed men want the government to do about prostate cancer screening—a qualitative analysis. BMJ open 2014;4(4):e004682.

50. Rychetnik L, Carter SM, Abelson J, et al. Enhancing citizen engagement in cancer screening through deliberative democracy. J Nat Cancer Inst 2013;105(6):380-86.

51. Paul C, Nicholls R, Priest P, et al. Making policy decisions about population screening for breast cancer: The role of citizens' deliberation. Health Policy 2008;85(3):314-20.

52. Bombard Y, Abelson J, Simeonov D, et al. Eliciting ethical and social values in health technology assessment: A participatory approach. Soc Sci \& Med 2011;73(1):135-44. 


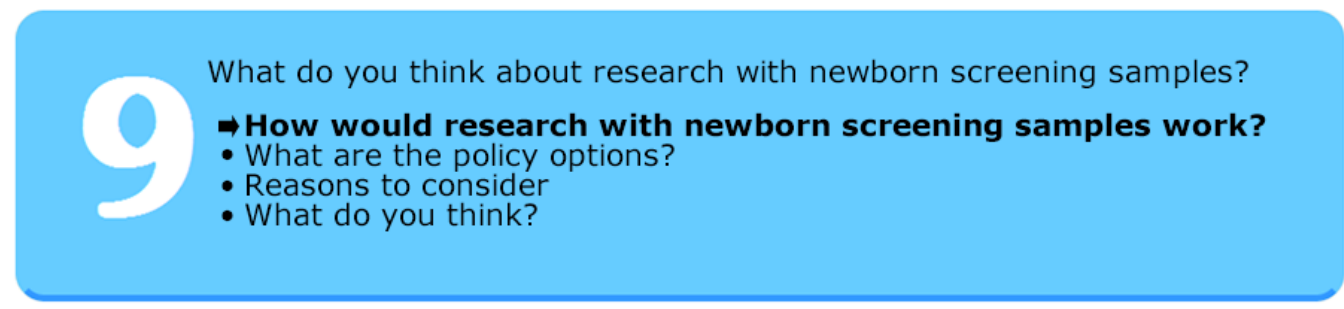

As you know, a few drops of blood are taken from babies' heels for newborn screening. After blood samples are tested for disease, leftover samples are kept so that the newborn screening program can use them to make sure the program is working properly. For example, the laboratory can re-test old samples to make sure that they have found the diseases they should have found.

These leftover samples could also be made available for future medical research. Many different kinds of medical research could be done with these samples because they provide information about almost all the babies in a province or country. So far, not a lot of research has been done with these samples in Canada.

\section{Conditions of Research}

If research with newborn screening samples is allowed, the following conditions would have to be met.

\section{All research would have to meet strict scientific and ethical standards:}

For any research to happen, it would have to be reviewed and approved by a "Research Ethics Board". Research Ethics Boards are responsible for all research conducted in universities and hospitals in Canada; they usually include physicians, researchers, lawyers, ethicists and members of the public

\section{All personal information would be removed to protect privacy:}

Information about the baby (e.g., name, address, etc.) would be removed and a number would be used to identify the sample. It would be possible to link the sample to personal health records using this number, but the linking procedure would be rigorously secured. Data would only be analyzed at group level and nobody who heard about the study would be able to identify who participated.

The newborn screening program would be responsible:

In each province, the newborn screening program would have to decide what type of research could be done. 
Next, please answer the following questions about what you have just learned.

\begin{tabular}{|c|c|c|}
\hline & True & False \\
\hline $\begin{array}{l}\text { Leftover samples collected for newborn screening can be used } \\
\text { to make sure that the program is working properly. }\end{array}$ & & \\
\hline $\begin{array}{l}\text { Leftover samples collected for newborn screening could be } \\
\text { useful for many different kinds of medical research. }\end{array}$ & & \\
\hline $\begin{array}{r}\text { Researchers working with leftover samples would have access } \\
\text { to personal information about babies (e.g., names and } \\
\text { addresses). }\end{array}$ & $C$ & 0 \\
\hline
\end{tabular}

652

Let's see how you did on those questions.

$\mathrm{X}$

1. Leftover samples collected for newborn screening can be used to make sure that the program is working properly. You said this answer was False.

Actually, this statement is true. Leftover samples collected for newborn screening can be used to make sure that the program is working properly. For example, samples can be re-tested to make sure the results are accurate.

$\mathrm{X}$

2. Leftover samples collected for newborn screening could be useful for many different kinds of medical research. You said this answer was False.

Actually, this statement is true. Because they provide information about almost all the babies in a province or country, leftover samples could be useful for many different kinds of medical research.

X

3. Researchers working with leftover samples would have access to personal information about babies (e.g., names and addresses). You said this answer was True.

Actually, this statement is false. Researchers would not have access to babies' personal information. 
Appendix 2a: Policy option presented to non-reasoning arm: An example

What do you think about research with newborn screening samples?

- How would research with newborn screening samples work?

- What are the policy options?

- Reasons to consider

$\Rightarrow$ What do you think?

Ask for permission: Parents are asked for their permission to store their baby's sample for future research. Unless parents agree to research, their baby's sample will not be used. Is this an acceptable or unacceptable policy option?

(Please check only one.)

667

668

669

670

671

672

673

674

\section{Appendix 2b: Forced choice question presented to non-reasoning arm}

What do you think about research with newborn screening samples?

- How would research with newborn screening samples work?

- What are the policy options?

- Reasons to consider

$\Rightarrow$ What do you think?

Of these four policy options, which do you think is the best?

(Please check only one.)

No research: The samples are destroyed after newborn screening, so that no research is possible.

Ask for permission: Parents are asked for their permission to store their baby's sample for future research. Unless parents agree to research, their baby's sample will not be used.

Assume permission: Parents are not asked for their permission to use their baby's sample for future research; permission is assumed but there is a clear process for parents to opt out.

No permission needed: Parents are not asked for their permission to use their baby's sample for future research; permission is not considered necessary. 


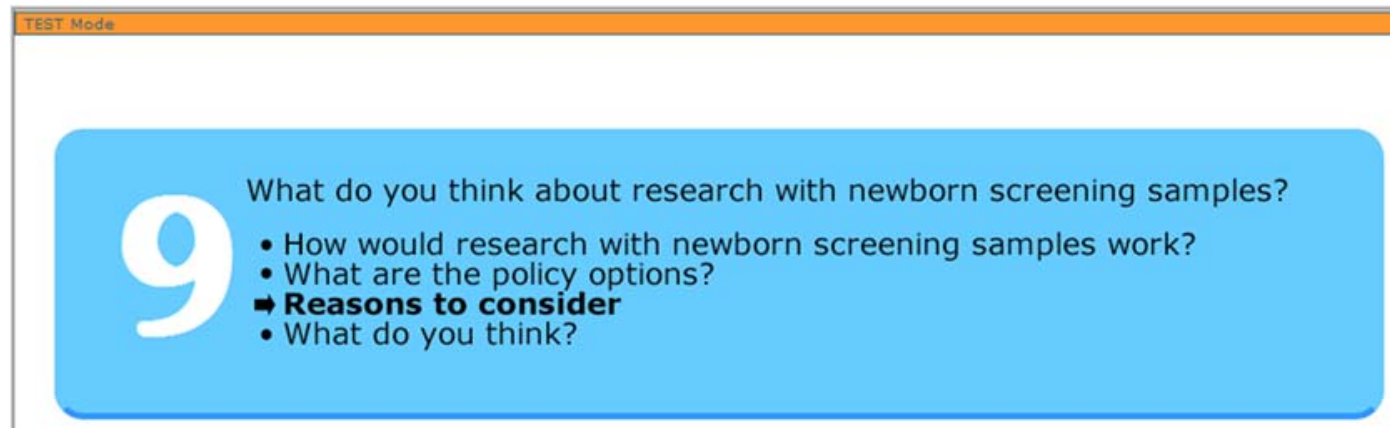

People disagree about the different policy options. The following are some important reasons to consider when thinking about policy options for medical research with leftover newborn screening samples:

Important research opportunity

We should take advantage of the research

opportunity provided by a program that collects samples from almost all babies born in a

province or country. This allows researchers to understand patterns of health and disease in the population.

\section{Consent has costs}

Obtaining consent is a complicated process that takes a great deal of time and money.

Medical research can be trusted We have good systems in place to ensure that only high quality research is done, and to protect the privacy and confidentiality of research participants.
Research is not the goal

We should not lose focus on the primary purpose of newborn screening, which is to ensure that babies with treatable diseases are identified early. Medical research may be important, but it doesn't have to happen through newborn screening.

Consent is necessary

Individuals should have a choice about whether or not they want to participate in research, regardless of the costs.

Research protections aren't always enough Despite all of the protections to ensure that research is high quality, and that the privacy and confidentiality of research participants is maintained, things can go wrong. 
681 Appendix 3b: Policy option presented to reasoning arm: An example

What do you think about research with newborn screening samples?

- How would research with newborn screening samples work?

- What are the policy options?

- Reasons to consider

$\Rightarrow$ What do you think?

Ask for permission: Parents are asked for their permission to store their baby's sample for future research. Unless parents agree to research, their baby's sample will not be used. Is this an acceptable or unacceptable policy option?

(Please check only one.)

\begin{tabular}{|cccc|}
$\begin{array}{c}\text { Completely } \\
\text { unacceptable option }\end{array}$ & $\begin{array}{c}\text { Somewhat } \\
\text { unacceptable option }\end{array}$ & $\begin{array}{c}\text { Somewhat } \\
\text { acceptable option }\end{array}$ & $\begin{array}{c}\text { Completely } \\
\text { acceptable option }\end{array}$ \\
\hline & & & \\
\hline
\end{tabular}

What reason had the strongest influence on your answer?

(Please check only one.)

682

683

684

685

686

687

688

689

690

691

692

693

694

695

696

697

698

699 


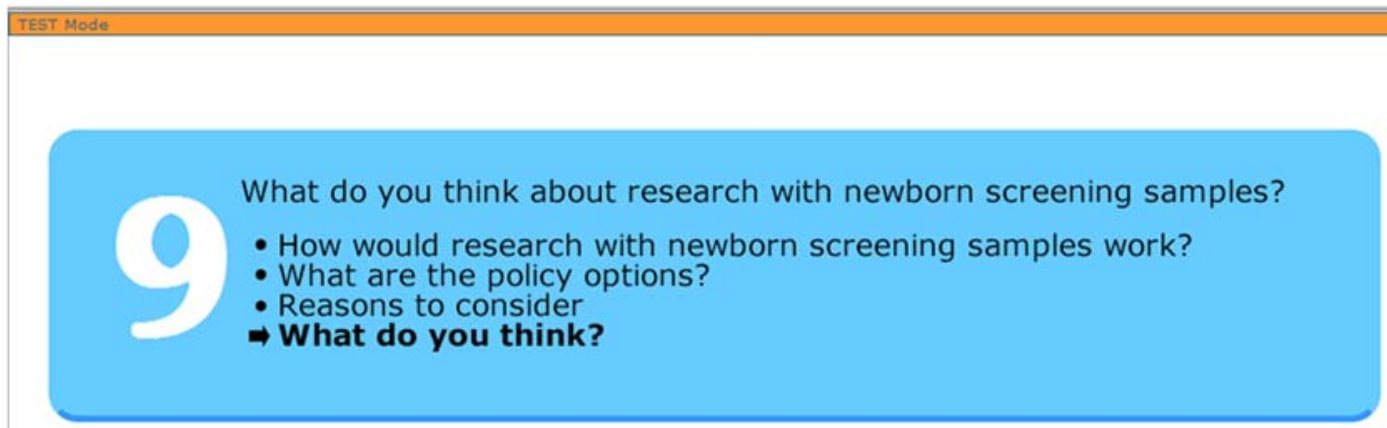

Of these four policy options, which do you think is the best?

(Please check only one.)

No research: The samples are destroyed after newborn screening, so that no research is possible.

Ask for permission: Parents are asked for their permission to store their baby's sample for future research. Unless parents agree to research, their baby's sample will not be used.

Assume permission: Parents are not asked for their permission to use their baby's sample for future research; permission is assumed but there is a clear process for parents to opt out.

No permission needed: Parents are not asked for their permission to use their baby's sample for future research; permission is not considered necessary.

What reason had the strongest influence on your answer?

(Please check only one.)

Important research opportunity

Consent has costs

Medical research can be trusted
Research is not the goal

Consent is necessary

Research protections aren't always enough

Before you answered this questionnaire, did you know that the blood samples collected through newborn screening could be stored and made available for medical research?

(Please check only one.)

Yes, I knew.

No, I had never heard of it /I only came to know of it through this questionnaire. 